\title{
CYBERBULLYING DAN INTERAKSI SOSIAL PADA REMAJA KELAS XI SMA DI SURABAYA
}

\author{
Chindy Maria Orizani, Monica Ganadhi The \\ Prodi D3 Keperawatan, STIKes Adi Husada \\ J1. Kapasari No. 95 Surabaya, Jawa Timur, Indonesia \\ chindyorizani@gmail.com
}

\begin{abstract}
Abstrak
Teknologi, informasi, dan komunikasi berkembang pesat memudahkan remaja berkomunikasi melalui social media bahkan untuk hal negatif seperti perundungan maya/cyberbullying. Korban cyberbullying menerima perlakuan tidak menyenangkan mengalami kesulitan dalam perkembangan psikologisnya, berdampak pada ketidakmampuan seorang remaja berinteraksi sosial dengan baik. Tujuan dari penelitian untuk mengetahui hubungan cyberbullying dengan interaksi sosial pada remaja kelas XI SMA di Surabaya. Penelitian menggunakan desain studi korelasi dan pendekatan cross sectional. Populasi penelitian yaitu siswa-siswi kelas XI SMA berjumlah 142 orang, sampel diambil sebanyak 105 orang secara simple random sampling. Hasil penelitian menunjukkan kejadian cyberbullying rendah dengan interaksi sosial sedang sebanyak 42 responden (40\%). Hasil uji Spearman Rank Test didapatkan tidak ada hubungan cyberbullying dan interaksi sosial, nilai $p=0,516$ dan $r=-0,064$. Remaja, diharapkan memahami dampak cyberbullying dan lebih tanggap terhadap kejadian cyberbullying yang terjadi di sekitarnya. Orang tua dan sekolah dapat memberikan pendidikan tentang cara menggunakan teknologi dengan bijak.
\end{abstract}

Kata kunci: perundungan maya, interaksi sosial, remaja.

\begin{abstract}
Technology, information, and communication are growing rapidly making it easy for teens to communicate through social media even for negative things like cyberbullying. Victims of cyberbullying receiving unpleasant treatment experience difficulties in their psychological development, impacting on the inability of a teenager to interact socially well. The purpose of this study was to determine the relationship of cyberbullying with social interaction in high school class XI teenagers in Surabaya. The study uses a correlation study design and cross sectional approach. The population of the study was 142 high school students in class XI, 105 samples were taken by simple random sampling. The results showed a low incidence of cyberbullying with moderate social interactions of 42 respondents (40\%). Spearman Rank Test results obtained no correlation between cyberbullying and social interaction, $p$ value $=0.516$ and $r=-0.064$. Teenagers are expected to understand the impact of cyberbullying and be more responsive to cyberbullying events that occur around them. Parents and schools can provide education on how to use technology wisely
\end{abstract}

Keywords: cyberbullying, social interaction, adolescent.

\section{PENDAHULUAN}

Teknologi berkembang pesat saat ini sangat membantu memudahkan remaja berkomunikasi melalui social media tidak hanya digunakan hal positif, namun juga halhal negatif seperti perundungan. Perundungan maya atau lebih dikenal cyberbullying sudah sering terjadi pada kalangan remaja dimana mereka sangat aktif menggunakan social media. Tidak sedikit korban cyberbullying menerima perlakuan tidak menyenangkan seperti diejek, dihina, diintimidasi, atau dipermalukan. Pengaruh dari kejadian tersebut bagi korban cyberbullying juga beragam, mulai dari rasa minder, sulit mempercayai orang lain, menghindari interaksi sosial, menjauhi teman sebaya, menyendiri, depresi, hingga berujung

Corresponding author:

Chindy Maria Orizani

chindyorizani@gmail.com 
pada kematian. Interaksi sosial merupakan suatu proses berkomunikasi dan media dalam membentuk suatu hubungan sosial. Kemampuan dalam berinteraksi sosial tidak serta-merta dapat dimiliki oleh seseorang. Seorang remaja berada dalam masa pengembangan psikologinya memiliki pengaruh besar terhadap kemampuan sosialnya. Jika seseorang remaja mengalami tindakan cyberbullying, sangat besar kemungkinannya remaja tersebut mengalami kesulitan dalam pengembangan psikologisnya berdampak pada ketidakmampuan seorang remaja dalam berinteraksi sosial dengan baik.

Cyberbullying menjadi mendunia setelah terjadi peningkatan pada kasus bunuh diri, pemerkosaan, dan pelecehan seksusal. Dampak cyberbullying muncul dan mempengaruhi kepribadian remaja juga menciptakan kecemasan sosial, dimana remaja merupakan masa peralihan untuk menemukan jati dirinya beresiko tinggi mengalami kegagalan dalam perkembangan psikologinya dan itu disebabkan oleh komentar-komentar negatif diterima di dunia nyata dan maya. Hal itu berpengaruh terhadap perilaku remaja, terhadap bagaimana mereka menilai diri dan bagaimana berinteraksi dengan orang lain, bahkan jika seseorang sudah tidak mengalami cyberbullying. Cyberbullying dapat merusak rasa aman dan berharga, membuat seseorang merasa takut dan menghindari interaksi sosial secara langsung maupun secara online.

Hasil penelitian pada remaja di Amerika Serikat, menunjukkan bahwa 20\% siswa sekolah menengah di Amerika Serikat menunjukkan pernah dirundung dan $15 \%$ melaporkan dirundung di dunia maya (Center for Disease Control, 2015). Dari penelitian terhadap 201 pelajar dari 16 universitas di Amerika Serikat ditemukan bahwa 85,2\% pelajar menjadi korban cyberbullying (Poole, 2017). Survei dilakukan oleh Sameer dan Patchin menunjukkan bahwa dari 4.972 responden berusia 12-17 tahun di Amerika, terdapat 36,5\% responden pernah mengalami cyberbullying (Sameer \& Patchin, 2019). Di Indonesia, data diterima dari Komisi Perlindungan Anak Indonesia, pada tahun 2018, kasus cyberbullying mencapai 209 kasus. Sangat berbeda jauh dengan Tahun 2015 dimana tidak ada kasus cyberbullying dilaporkan (Abdul, 2019).

Penyebab tindakan cyberbullying adalah keinginan pelaku untuk melakukan perundungan karena iri dengan orang lain, ingin menunjukkan jati diri, dan karena pelaku senang menyakiti perasaan korban. Penyebab lain juga karena pelaku memiliki perasaan minder dan terancam. Untuk melindungi egonya dan agar merasa hebat, mereka membuat orang lain merasa buruk terhadap diri mereka sendiri. Beberapa pelaku juga melakukan bullying untuk meningkatkan popularitasnya, mendapatkan perasaan berkuasa, atau bahkan untk melarikan diri dari masalah mereka. Pelaku tidak takut melakukan cyberbullying, hal itu karena mudahnya menggunakan dan membuat akun palsu. Pelaku bisa dengan bebas melakukan aksi bully-nya tanpa takut identitasnya akan diketahui oleh korban dan orang lain. Semakin mudah melakukan cyberbullying berbanding lurus dengan semakin banyak korban dari cyberbullying. Cyberbullying berdampak terhadap emosional dan psikologi korban. Korban mungkin merasakan depresi, stres dan cemas, kesepian, dan kesulitan tidur. Dampak lainnya juga ada pada nilai akademiknya, dan tampak pada pola makan buruk, menghindari interaksi sosial dengan orang lain, sulit berkonsentrasi, rendahnya harga diri, perasaan tidak berharga, dan bahkan pemikiran untuk bunuh diri. Menurut Sam (2019), peningkatan jumlah kasus bunuh diri pada remaja berhubungan langsung dengan cyberbullying. Salah satu penelitian tentang cyberbullying mengindikasi bahwa cyberbullying memiliki dampak terhadap perasaan korban tentang keamanannya di 
sekolah. Selain itu, cyberbullying juga berdampak negatif dimana merusak motivasi korban cyberbullying.

Solusi mengatasi dampak dari cyberbullying adalah dengan mengembangkan sikap saling menghormati, menciptakan komunitas-komunitas anticyberbullying, dan menyediakan sarana konseling/pendukung untuk korban-korban cyberbullying (Navarro et al., 2015). Keluarga harus mendorong remaja untuk menceritakan tentang tindakan cyberbullying yang dialami. Keluarga, khususnya orang tua, harus bisa menjadi tempat yang aman dimana remaja dapat menceritakan masalah apapun. Bergantung pada situasi yang terjadi, remaja juga bisa memilih untuk berbicara dengan guru, pembina sekolah, dan psikolog atau psikiater.

Penelitian ini memiliki tujuan untuk mengetahui hubungan cyberbullying dengan interaksi sosial pada remaja Kelas XI SMA di Surabaya sebagai upaya untuk mengetahui dampak cyberbullying terhadap interaksi sosial pada remaja.

\section{METODE PENELITIAN}

Jenis penelitian menggunakan desain korelasional (hubungan/asosiasi) dengan pendekatan cross sectional Populasi penelitian adalah seluruh remaja kelas XI SMA di Surabaya berjumlah 142 orang dan sampel penelitian ini remaja pernah mengalami cyberbullying di SMA berada di Surabaya sebanyak 105 orang. Teknik pengumpulan data menggunakan simple random sampling. Instrument pengumpulan data menggunakan lembar kuesioner cyberbulling modifikasi dari Krisnawan (2018) yang terdiri dari 10 pertanyaan berisi 10 indikator cyberbulling yaitu frapping, dissing, trolling, catfishing, phishing, stalking, blackmailing, photografh/video, shunning, dan sexting. Lembar kuesioner untuk memperoleh data dari interaksi sosial modifikasi dari Sutarjo (2014) yang terdiri dari 10 pertanyaan. Penelitian ini menggunakan perangkat lunak untuk tabulasi dan analisis data yaitu Spearmen Rank Test.

\section{HASIL}

Tabel 1

Distribusi Frekuensi Responden Berdasarkan Jenis Kelamin dan Usia pada Remaja SMA di Surabaya $(\mathbf{n}=\mathbf{1 0 5})$

\begin{tabular}{|c|c|c|c|}
\hline No. & Karakteristik & Frekuensi & Persentase \\
\hline \multicolumn{4}{|c|}{ 1. Jenis Kelamin } \\
\hline & Laki-laki & 40 & $38 \%$ \\
\hline & Perempuan & 65 & $62 \%$ \\
\hline \multicolumn{4}{|c|}{ 2. Usia } \\
\hline & 14 Tahun & 1 & $2 \%$ \\
\hline & 15 Tahun & 16 & $15 \%$ \\
\hline & 16 Tahun & 37 & $35 \%$ \\
\hline & 17 Tahun & 27 & $26 \%$ \\
\hline & 18 Tahun & 13 & $12 \%$ \\
\hline & 19 Tahun & 11 & $10 \%$ \\
\hline
\end{tabular}

Berdasarkan Tabel 1 menunjukkan sebagian besar responden adalah perempuan sebanyak 65 responden $(62 \%)$ dan sebagian besar responden berusia 16 tahun (35\%). 
Tabel 2

Hubungan Cyberbullying dengan Interaksi Sosial pada Remaja SMA di Surabaya (n= 105)

\begin{tabular}{rrcc}
\hline No. & Karakteristik & Frekuensi & Persentase \\
\hline 1. & Cyberbullying & 1 & \\
& Tinggi & $1 \%$ \\
Sedang & 20 & $19 \%$ \\
Rendah & 84 & $80 \%$ \\
2. Interaksi sosial & & \\
& Baik & 36 & $34 \%$ \\
& Cukup & 51 & $49 \%$ \\
& Kurang & 18 & $17 \%$ \\
\hline
\end{tabular}

Nilai uji Spearman Rank $(p)=0,516$

Nilai $\mathbf{r}=-\mathbf{0 , 0 6 4}$

Berdasarkan Tabel 2 menunjukkan hampir seluruh remaja SMA di Surabaya menjadi responden mengalami cyberbullying tingkat rendah yaitu sebanyak 84 responden (80\%) dan sebagian besar remaja SMA di Surabaya menjadi responden cukup dalam berinteraksi sosial yaitu sebanyak 51 responden $(49 \%)$. Hasil nilai $(p=0,516)$ dan nilai $(r=-0,064)$ menggunakan uji statistik Spearman Rank Test menunjukkan tidak ada hubungan yang signifikan antara cyberbullying dan interaksi sosial.

\section{PEMBAHASAN}

\section{Cyberbullying}

Berdasarkan hasil penelitian didapatkan kejadian cyberbullying dialami dengan kategori tinggi sebanyak 1 responden (1\%), cyberbullying dialami dengan kategori sedang sebanyak 20 responden (19\%), dan cyberbullying dialami dengan kategori rendah sebanyak 84 responden (80\%). Persentase cyberbullying terbesar berada pada kategori rendah, siswa telah memahami konsep tentang konsep tentang cyberbullying. Cyberbullying dinilai sebagai kegiatan yang tidak bermanfaat, menyakiti perasaan teman atau seseorang dan bahkan mengakibatkan kematian. Penelitian menunjukkan seluruh indikator cyberbullying pernah dilakukan namun dalam frekuensi kecil. Cyberbullying pada penelitian ini memiliki 10 indikator yaitu fraping dimana seseorang mengakses akun media sosial korban dan menirukan mereka dengan tujuan untuk bergurau atau menghancurkan reputasinya; dissing yaitu menyebar atau mempublikasikan informasi kejam secara online untuk menghancurkan reputasi seseorang atau pertemanan dengan orang lain, trolling yaitu menghina seseorang secara online untuk mendapatkan respon dari mereka; catfishing yaitu mencuri identitas pribadi seseorang untuk menciptakan kembali identitas online dengan tujuan untuk menipu, phising yaitu suatu cara untuk menipu, membujuk atau memanipulasi korban untuk memberitahu informasi pribadi dan/atau informasi keuangan tentang diri sendiri dan/atau orang peduli, stalking yaitu menguntit saat seseorang mempublikasikan informasi pribadinya di jejaring sosial, penguntit dapat mengirimkan pesan pribadi, hadiah misterius ke rumah seseorang, dan lain-lain, blackmail yaitu e-mail, telepon, pesan pribadi dari orang tidak dikenal dilakukan oleh orang yang dirahasiakan; photographs and video yaitu mengancam untuk menyebarkan foto dan videonya secara publik kecuali korban mengikuti keinginan mereka, shunning yaitu menghindari, mengacuhkan, atau menolak seseorang untuk berpartisipasi dijejaring social, sexting yaitu mengirim foto atau pesan seksual lewat handphone. Mereka cenderung sebagai pengamat, hanya melihat tanpa menunjukkan respon maupun ikut andil didalam kegiatan cyberbullying. 
Hasil penelitian ini didukung oleh hasil penelitian Rahayu (2012) di Jawa Tengah dan Yogyakarta terhadap 363 siswa remaja berusia 12-19 tahun (tingkat SMP dan SMU) terdapat $28 \%$ siswa mengaku pernah mengalami cyberbullying dan $1 \%$ siswa mengatakan sering mengalaminya, 29\% siswa pernah dan sering mengalami cyberbullying didapatkan fakta $70 \%$ siswa mengatakan bahwa perundungan hanya terjadi satu atau dua kali saja lalu berhenti, 17\% mengatakan mendapatkan perlakuan bully beberapa kali dalam satu minggu, $6 \%$ mendapatkan perlakuan tersebut satu minggu sekali, dan $6 \%$ siswa mendapatkan perlakuan bullyrt[] dua atau tiga kali setiap bulannya. Hal ini menunjukkan bahwa sebagian besar anak usia SMA mengalami cyberbullying pada tingkat rendah. Tingkat rendah dimaksud adalah perlakuan cyberbullying diterima berada dalam frekuensi rendah (tidak sering terjadi). Meskipun dampaknya dapat menyakiti hati korban, namun angka 70\% menunjukkan serangan hanya terjadi satu atau dua kali, belum bisa dimasukkan dalam kategori cyberbullying. Rifauddin (2016) menyatakan cyberbullying adalah versi lain perundungan yaitu perilaku seseorang atau kelompok secara sengaja dan berulang kali melakukan tindakan menyakiti orang lain melalui media komputer, telepon, dan alat elektronik lainnya. Menurut Rahayu (2012), rendahnya persentase kejadian cyberbullying dikarenakan remaja menganggap perlakuan cyberbullying adalah sesuatu yang lazim terjadi dikalangannya. Namun bukan berarti kita dapat menganggap remeh cyberbullying dan dampaknya terhadap remaja. Meskipun remaja terlihat sudah terbiasa dengan cyberbullying, namun masih ada dampak jangka panjang yang mungkin dapat terjadi.

Menurut peneliti, adanya kejadian cyberbullying dikalangan remaja dikarenakan masih terdapat kelompok-kelompok remaja mencoba mendapatkan pengakuan dengan cara melakukan perundungan. Mudahnya melakukan cyberbullying juga membuat beberapa remaja menjadikan cyberbullying sebagai media untuk merundung orang tidak dapat mereka rundung secara langsung. Korban bullying-pun mungkin melakukan cyberbullying sebagai cara untuk membalas perlakuan bullying yang diterima. Namun siswa sekarang lebih memilih untuk tidak melakukan cyberbullying karena perundungan merupakan hal yang kuno, mereka cenderung memilih mengikuti kegiatan yang bermanfaat bagi masa depan mereka seperti mengikuti ekstrakurikuler sekolah, bergabung dalam komunitas di luar sekolah yang bisa meningkatkan interaksi sosial dan mencari pengalaman berkomunikasi yang baik dengan orang lain. Remaja juga lebih baik menyimpan masalah perundungan yang mereka alami dan tidak melaporkannya kepada orang tua maupun guru. Hal tersebut dikarenakan mereka berupaya menyelesaikan sendiri masalah yang dialami dan menjadikan perundungan sebagai pelajaran/ pengalaman hidup untuk menghadapi masalah yang jauh lebih besar dikemudia hari.

\section{Interaksi Sosial}

Hasil penelitian menunjukan persentase interaksi sosial terbesar kategori cukup sebanyak 51 responden (49\%). Interaksi sosial dalam penelitian ini memiliki tiga indikator yaitu interaksi antara individu terjadi saat dua individu bertemu, interaksi individu dengan kelompok, dan interaksi antar kelompok. Interaksi sosial sudah dimulai sejak anakanak, dimulai dari lingkungan keluarga kemudian meluas seiring dengan bertambahnya usia, mulai masuk sekolah dan mengenal banyak orang baru. Mereka mendapatkan pembelajaran dini tentang nilai dan norma dari orang tua, kemudian mengenal nilai dan norma dari masyarakat ia kenal. Seiring berkembangnya kemampuan berkomunikasi dan adanya kontak sosial maka akan mempengaruhi interaksi sosial remaja. Interaksi yang ditunjukkan oleh remaja dikarenakan adanya penerimaan yang baik oleh lingkungannya terutama di keluarga, sekolah dan masyarakat. Mereka membangun kontak dan komunikasi yang baik dengan 
orang lain, kelompok dan masyarakat, misalnya dengan adanya keaktifan mengikuti kegiatan penugasa berkelompok dan tergabung dengan kelompok ekstrakurikuler.

Hasil penelitian diatas sesuai dengan penelitian dari Sutarjo (2014) menuliskan hasil penelitian interaksi sosial dengan jumlah responden 89 , hasil yang diperoleh adalah interaksi sosial kategori sangat baik dengan jumlah 7 responden $(7,8 \%)$, kategori baik dengan jumlah 32 responden $(35,9 \%)$, kategori cukup dengan jumlah 45 responden $(50,5 \%)$, dan kategori kurang baik dengan jumlah 5 responden $(5,6 \%)$. Hal ini menunjukan sebagian besar remaja SMA memiliki kemampuan berinteraksi sosial sedang. Menurut Sunaryo (2010) interaksi sosial terjadi jika ada komunikasi dan kontak sosial. Kontak sosial dapat terjadi dengan dan tanpa sentuhan fisik, seperti bertelepon atau berkirim surat. Interaksi sosial dapat membantu remaja dalam memenuhi salah satu tugas perkembangan remaja menurut Pieter \& Lubis (2010) yaitu memperoleh hubungan baru dan lebih matang dengan teman-teman sebaya.

Menurut peneliti, kemampuan berinteraksi sosial remaja SMA berada dalam kategori cukup karena dapat dilihat dari frekuensi remaja dalam menggunakan teknologi komunikasi, dimana banyaknya media-media sosial mendukung komunikasi dengan orang lain, dari situlah muncul interaksi sosial. Seiring dengan berkembangnya remaja ke masa dewasa, maka kebutuhan untuk berinteraksi dengan orang lain dan lingkungan sosial juga akan semakin meningkat. Remaja berinteraksi sosial guna memenuhi kebutuhan fisik maupun psikologis, menunjukkan eksistensi, menghargai kegiatan yang dijalankan, dan memenuhi tugas perkembangannya dan disadari berpengaruh terhadap kepribadiannya dimasa mendatang.

\section{Hubungan Antara Cyberbullying dengan Interaksi Sosial pada Siswa SMA di Surabaya}

Hasil penelitian didapatkan hasil analisa statistik korelasi dari Spearman Rank Test dimana diperoleh nilai $p$ value $=0,516$ dan $\alpha=0,05$ dimana $p>\alpha$ yang artinya $h_{0}$ diterima yaitu tidak adanya hubungan antara cyberbullying dengan interaksi sosial pada siswa SMA di Surabaya. Hasil penelitian ini menunjukkan bahwa meskipun semua responden pernah mengalami cyberbullying, namun hal tersebut tidak terlalu berpengaruh terhadap kualitas interaksi sosialnya. Seseorang melakukan cyberbullying bisa dengan/atau tanpa niat melakukannya. Niat cyberbullying sengaja muncul untuk membuat malu atau melakukan balas dendam bahkan sekedar untuk mencari perhatian dari obyek yang dituju. Sedangkan yang melakukan tanpa niat, sekedar untuk mempermainkan dan dianggap sebuah lelucon mengisi hari mereka. Sebagian remaja terkadang tidak menyadari tulisan di media sosial merupakan sebuah perundungan, mereka menganggap hal tersebut suatu hal wajar dan menganggap hal itu remeh sehingga tidak mempengaruhi psikologis mereka secara umum. Mereka juga menyebutkan cyberbullying sebagai bumbu kehidupan, justru menganggap cemooh di media sosial pertanda mereka terkenal dan diperhatikan banyak orang. Hal tersebut tidak mempengaruhi cara berkomunikasi, kontak dengan lingkungannya dan interaksi sosial.

Hasil penelitian ini sesuai dengan penelitian Rahayu (2012), sebagian besar remaja tidak menyadari dampak cyberbullying baik positif atau negatif dan menganggap bahwa perlakuan cyberbullying adalah sesuatu yang lazim dilakukan oleh para remaja. Mereka mulai "terbiasa" dengan tindakan cyberbullying dilakukan maupun yang diterima. Keterbiasaan tersebut membuat remaja tidak menganggap semua perlakuan sebagai tindakan cyberbullying. Mereka cenderung menjadi pengamat dan tidak ingin terlibat pada kegiatan perundungan dan berkembangnya stigma pada remaja, jika mereka melakukan cyberbullying, menunjukkan mereka adalah remaja yang 
memiliki masalah internal diri mereka (Gahagan et al., 2016).

Sementara menurut peneliti, minimnya kejadian cyberbullying pada kalangan remaja SMA karena didukung oleh lingkungan sosial (keluarga dan sekolah) baik. Remaja dengan hubungan keluarga harmonis dan orang tua perhatian, lingkungan sekolah yang tertib atau religious, lingkungan pergaulan yang baik membuat persentase remaja melakukan ataupun mendapatkan perlakuan cyberbullying semakin kecil. Ada beberapa tantangan membuat cyberbullying sulit dicegah. Pertama, kurangnya kesadaran dari pelaku maupun korban cyberbullying terhadap dampak. Kenyataan bahwa remaja mengganggap itu hal yang wajar merupakan bukti bahwa remaja sudah mulai terbiasa dan tidak menganggap serius kejadian cyberbullying. Mereka berada diposisi sebagai penonton-pun tidak menganggap serius hal tersebut.Masalahnya tidak semua remaja bisa berpikir seperti itu karena ada faktor-faktor predisposisi dapat memperburuk dampak cyberbullying. Kedua, kurangnya edukasi dan perhatian dari orang tua terhadap kegiatan penggunaaan teknologi, informasi, dan komunikasi dilakukan oleh remaja. Orang tua merasa bahwa mereka tidak dapat mengikuti perkembangan teknologi masa kini. Ketiga, sekolah lebih berfokus pada penggunaan teknologi saja, akibatnya sekolah kurang berkontribusi dalam menjelaskan tentang penggunaan teknologi secara bijak (Silva et al., 2017). Ada cara yang dapat dilakukan untuk mengurangi kejadian cyberbullying. Bagi remaja, diharapkan dapat memahami dampak cyberbullying, menumbuhkan perasaan peka dan tidak menyepelekan kejadian cyberbullying yang terjadi di sekitarnya. Bagi orang tua dan sekolah dapat memberikan pendidikan tentang cara menggunakan teknologi dengan bijak. Alihalih dianggap sebagai hal yang wajar terjadi, remaja, orang tua, dan pihak sekolah harus berusaha untuk menekan angka kejadian dari cyberbullying. Para penegak hukum juga dapat membuat aturan-aturan dan memberikan sosialisasi tentang cara menggunakan teknologi, dampak yang terjadi jika menyalahgunakan teknologi, dan hukuman yang akan didapatkan (Notar et al., 2013).

\section{KESIMPULAN}

Remaja Kelas XI SMA di Surabaya menunjukkan hampir seluruhnya pernah mengalami cyberbullying kategori rendah dan hampir separuh memiliki kemampuan berinteraksi sosial dalam kategori cukup. Tidak adanya hubungan antara cyberbullying dan interaksi sosial remaja kelas XI SMA dengan nilai $\alpha$ atau $p=0,516$ dan nilai $\mathrm{r}=$ 0,064. Diperlukan program edukasi yang sudah diteliti sebelumnya yang dapat dilaksanakan oleh pihak sekolah agar dapat meningkatkan sosial interaksi siswa-siswi dan penggunaan teknologi secara bijak dan informasi tentang cyberbullying dan dampaknya.

\section{DAFTAR PUSTAKA}

Abdul, R. A. (2019). Cyberbullying Meningkat Pesat, Catat Pesan KPAI.

Center for Disease Control. (2015). Understanding Cyberbullying: Fact Sheet.

Gahagan, K., Vaterlaus, J. M., \& Frost, L. R. (2016). College Student Cyberbullying on Social Networking Sites: Conceptualization, Prevalence, and Perceived Bystander Responsibility. Computers in Human Behavior, 55, 1097-1105.

https://doi.org/10.1016/j.chb.2015.11.01 9

Navarro, R., Yubero, S., \& Larranaga, E. (2015). Cyberbullying Across the Globe. Springer International Publishing.

Notar, C. E., Padgett, S., \& Roden, J. (2013). Cyberbullying: Resources for Intervention and Prevention. Universal 
Journal of Educational Research, 1(3), 133-145.

https://doi.org/10.13189/ujer.2013.01030 1

Pieter, H. Z., \& Lubis, N. L. (2010). Pengantar Psikologi dalam Keperawatan. Kencana Prenada Media Group.

Poole, S. P. (2017). The Experience of Victimization as the Result of Cyberbullying Among College Students: A study of Demographics, Self-Esteem, and Locus of Control. Electronic Theses and Dissertations.

Rahayu, F. S. (2012). Cyberbullying Sebagai Dampak Negatif Penggunaan Teknologi Informasi. Journal of Information System, 8(43), 22-31.

Rifauddin, M. (2016). Fenomena Cyberbullying pada Remaja (Studi Analisis Media Sosial Facebook). Khizanah Al-Hikmah: Jurnal Ilmu Perpustakaan, Informasi, Dan
Kearsipan, 4(1), 35-44.

Sam, C. (2019). Cyberbullying Facts and Statistics for 2016-2019.

Sameer, H., \& Patchin, J. W. (2019). 2019 Cyberbullying Data. Cyberbullying Research Center.

Silva, J. L. da, Oliveira, W. A. de, Mello, F. C. M. de, Andrade, L. S. de, Bazon, M. R., \& Silva, M. A. I. (2017). AntiBullying Interventions in Schools: A Systematic Literature Review. Ciencia e Saude Coletiva, 22(7), 2329-2340. https://doi.org/10.1590/1413-

81232017227.16242015

Sunaryo. (2010). Psikologi untuk Keperawatan. EGC.

Sutarjo, D. A. P. (2014). Hubungan Antara Interaksi Sosial Teman Sebaya dengan Penerimaan Sosial pada Siswa Kelas $X$ SMA Negeri 9 Yogyakarta. Universitas Negeri Yogyakarta. 